\title{
Hepatic resection for breast cancer metastases
}

\author{
AC OKARO ${ }^{1}$, DJ DURKIN ${ }^{1}$, GT LAYER $^{2}$, MW KISSIN $^{2}$, ND KARANJIA ${ }^{1}$
}

\author{
${ }^{1}$ Hepatobiliary and ${ }^{2}$ Breast Units, Department of Surgery, The Royal Surrey County Hospital, \\ Guildford, Surrey, UK
}

ABSTRACT

INTRODUCTION Hepatic resection is an established modality of treatment for colorectal cancer metastases. Resection of breast cancer liver metastases remains controversial, but has been shown to be an effective treatment in selected cases. This study reports the outcome of 8 patients with liver metastases from breast cancer.

PATIENTS \& METHODS 8 patients with liver metastases from previously treated breast cancer were referred for hepatic resection between September 1996 and December 2002. Six were eligible for liver resection. The mean age was 45.8 years. The resections performed included 1 segmentectomy and 5 hemihepatectomies of which one was an extended hemihepatectomy. One patient had a repeat hepatectomy 44 months after the first resection.

RESULTS There were no postoperative deaths or major morbidity. The resectability rate was $75 \%$. Follow-up periods range from 6 to 70 months with a median survival of 31 months following resection. There have been 2 deaths, one died of recurrence in the residual liver at 6 months and one died disease-free from a stroke. Of the remaining 4 patients, 1 has had a further liver resection at 44 months following which she is alive and 'disease-free' at 70 months. The one patient with peritoneal recurrence is alive 49 months after her liver resection with 2 patients remaining disease-free.

CONCLUSION Hepatic resection for breast cancer liver metastases is a safe procedure with low morbidity and mortality.

\section{KEYWORDS}

Breast cancer - Hepatic metastases - Hepatic resection

CORRESPONDENCE TO

Mr ND Karanjia, Consultant Gastrointestinal and Liver Surgeon, Hepatobiliary Unit, Department of Surgery, Royal Surrey County Hospital, Egerton Road, Guildford, Surrey GU2 7XX, UK. T: +44 (0)1483 464118; F: +44 (0)1483 304698; E: nariman.karanjia@ntlworld.com

Hepatic metastases are found in 55-75\% of autopsies performed on patients who died from breast cancer. ${ }^{1}$ Those patients who develop liver metastases from their treated breast cancer have a poor prognosis. ${ }^{2-6}$ Chemotherapy and hormone and biological therapies are capable of inducing response in some cases but the impact on overall survival remains unclear. ${ }^{6-10}$

Advances in surgical technique and technology have resulted in a reduction in the mortality and morbidity associated with liver surgery, ${ }^{11}$ facilitating liver resection in becoming widely accepted as an effective method of treating colorectal liver disease. ${ }^{12-15}$ The role of liver resection for metastases arising from breast cancer remains controversial. There are a growing number of reports from different units which show that mortality and morbidity following liver surgery for breast disease remain low and may provide a survival advantage for some patients. ${ }^{16-22}$ This study reviewed the outcome of 8 patients with liver metastases from previous breast cancer, 6 of whom had surgical excision of their liver deposits.

\section{Patients \& Methods}

Eight patients with liver metastases from previous breast cancer were referred for consideration of surgical excision between September 1996 and December 2002. Patients were examined and investigated by serum biochemistry (including tumour markers), mammography, skeletal scintigraphy, total body computerised tomography (CT) scanning, upper and lower gastrointestinal endoscopy. Liver imaging included ultrasound (transabdominal and intra-operative), MRI (Tesla enhanced) and spiral CT. Staging laparoscopy to exclude more extensive liver disease than anticipated and/or peritoneal disease preclude liver resection became routine from 2001. Hepatic parenchymal dissection is performed using an ultrasonic dissector and argon-beam coagulator, employing the technique of intermittent hepatic inflow occlusion to minimise blood loss as previously described. ${ }^{13}$ Data were collected prospectively. 


\section{Results}

The mean age at diagnosis of the breast primary was 45.8 years (range, 36-58 years). With the exception of a single patient, all the other 7 patients presented with metachronous liver deposits. The mean duration from the treatment of the primary breast cancer to the diagnosis of liver secondaries was 75 months (range, 24-144 months). In one patient, secondary liver deposits were detected at the time her breast cancer was diagnosed. All patients had received Anthracyline-containing chemotherapy after liver surgery.

Six patients underwent potentially curative liver resections while two patients were found to have inoperable disease (one with extensive superficial bilobar deposits and the other with peritoneal disease) at laparotomy. Two patients had single metastases, two had two, one had three and one had five metastases. The procedures performed are listed in Table 1 and range from a single segmentectomy to an extended hemihepatectomy. None of the patients required peri-operative blood transfusion and there was no mortality or major morbidity. Median hospital stay follow- ing liver resection was 8.5 days (range, 4-12 days). Microscopic margins were clear in all cases. There have been two deaths, one from a stroke and the other from liver recurrence over a follow-up period ranging from 2-62 months. Of the 4 patients still alive following their 'curative' resection, one developed peritoneal metastases 47 months after hepatic surgery diagnosed at laparoscopy performed for vague abdominal pain associated with rise in serum CA15.3 levels, another developed recurrent liver disease at 36 months, following a 12-month period of observation the recurrence remained isolated and unchanged in size, this was re-resected at 44 months and the patient remains alive and disease-free at 70 months. The last 2 patients are presently disease free. Table 1 summarises the treatment details.

\section{Discussion}

Invasive breast cancer is generally thought to be a systemic disease even at the time of presentation and even more so when remote metastases are detected. ${ }^{21,23,24}$ This may, in part, explain why surgical resection of liver metastases for

Table 1 Treatment summary

\begin{tabular}{|c|c|c|c|c|c|c|}
\hline $\begin{array}{l}\text { Patient } \\
\text { number }\end{array}$ & $\begin{array}{l}\text { Age at } \\
\text { diagnosis of } \\
\text { breast cancer } \\
\text { (years) }\end{array}$ & $\begin{array}{l}\text { Primary } \\
\text { treatment }\end{array}$ & $\begin{array}{l}\text { Tumour } \\
\text { pathology } \\
\text { (breast) }\end{array}$ & $\begin{array}{l}\text { Interval from } \\
\text { primary treatment } \\
\text { to diagnosis of } \\
\text { liver metastases } \\
\text { (months) }\end{array}$ & $\begin{array}{l}\text { Resection } \\
\text { ( } n=\text { number } \\
\text { of liver deposits } \\
\text { and size of } \\
\text { largest deposit) }\end{array}$ & Survival \\
\hline 1 & 58 & $M x+A x$ & $\mathrm{~T}_{4} \mathrm{G}_{2} \mathrm{~N}_{4 / 10}$ & 24 & $\begin{array}{l}\mathrm{R} \text { hepatectomy } \\
(n=2,25 \mathrm{~mm})\end{array}$ & $\begin{array}{l}\text { Died at 30/12 from } \\
\text { stroke, no signs } \\
\text { of recurrence }\end{array}$ \\
\hline 2 & 36 & $M x+A x$, Goserelin & $\mathrm{T}_{2} \mathrm{G}_{1} \mathrm{~N}_{0}$ & 54 (pre-op FEC) & Inoperable & Alive at $50 / 12$ \\
\hline 3 & 47 & WLE, DXT, TAM & $\mathrm{T}_{1} \mathrm{G}_{1} \mathrm{~N}_{0}$ & 144 & $\begin{array}{l}\text { Extended R hepatectomy } \\
(n=10,45 \mathrm{~mm}) \& \\
\text { segmentectomy II } \\
(n=7,20 \mathrm{~mm})\end{array}$ & $\begin{array}{l}\text { Rec disease at } \\
\text { 36/12; re-resected } \\
\text { 44/12; alive and } \\
\text { disease-free at } 70 / 12\end{array}$ \\
\hline 4 & 53 & $\begin{array}{l}\mathrm{WLE}+\mathrm{Ax}, \mathrm{CMF} \text {, } \\
\text { oophorectomy }\end{array}$ & $\mathrm{T}_{1} \mathrm{G}_{1} \mathrm{~N}_{1 / 15}$ & 48 & Inoperable & Alive at 33/12 \\
\hline 5 & 53 & $M x+A x$, TAM & $\mathrm{T}_{1} \mathrm{G}_{1} \mathrm{~N}_{1 / 14}$ & 60 & $\begin{array}{l}\text { R hepatectomy } \\
(n=1,18 \mathrm{~mm})\end{array}$ & $\begin{array}{l}\text { Alive with peritoneal } \\
\text { seedlings at } 57 / 12\end{array}$ \\
\hline 6 & 37 & $\begin{array}{l}\text { WLE + Ax, } \\
\text { CMF, DXT, TAM }\end{array}$ & $\mathrm{T}_{2} \mathrm{G}_{3} \mathrm{~N}_{4 / 34}$ & $\begin{array}{l}\text { Synchronous } \\
\text { (interval CMF) }\end{array}$ & $\begin{array}{l}\mathrm{L} \text { hepatectomy at } \\
10 / 12(n=1,30 \mathrm{~mm})\end{array}$ & $\begin{array}{l}\text { Recurrent liver } \\
\text { disease at } 3 / 12 \text {; } \\
\text { died at } 6 / 12\end{array}$ \\
\hline 7 & 36 & $M x+A x$ & $\mathrm{~T}_{3} \mathrm{G}_{3} \mathrm{~N}_{0}$ & $\begin{array}{l}120 \\
(n=2,35 \mathrm{~mm})\end{array}$ & $\begin{array}{l}\mathrm{R} \text { hepatectomy } \\
\text { at } 15 / 12\end{array}$ & Disease-free \\
\hline 8 & 47 & $\begin{array}{l}\text { WLE + Ax, } \\
\text { DXT, TAM }\end{array}$ & $T_{3} G_{2} N_{2 / 18}$ & 80 & $\begin{array}{l}L \text { hepatectomy }+ \\
\text { wedge resection } x \\
3(n=5,25 \mathrm{~mm})\end{array}$ & $\begin{array}{l}\text { Disease-free } \\
\text { at } 10 / 12\end{array}$ \\
\hline
\end{tabular}

Mx, mastectomy; Ax, axillary dissection; TAM, tamoxifen; WLE, wide local excision; DXT, radiotherapy; CMF, chemotherapy with cyclophosphamide, methotrexate and

5-fluorouracil; FEC, chemotherapy with 5-fluorouracil, epi-doxorubicin and cyclophosphamide; $T_{x} G_{x} N_{x}$, standard nomenclature for breast tumour size, grade and nodal status. 
breast cancer remains controversial. Suppression of growth of putative micrometastases is successful in $10 \%$ of patients using a combination of endocrine therapy and chemotherapy in the adjuvant setting. ${ }^{25}$ When this fails, the mainstay of managing distant metastatic disease relies on further treatment with second-line endocrine and chemotherapy. Hepatic metastases are found in $55-75 \%$ of autopsies on patients dying from breast cancer., ${ }^{1,26,27}$ Currently, in most centres, chemotherapy is usually considered the treatment of choice for patients with liver metastases from breast cancer even though the outlook following this form of treatment remains bleak, with median survival ranging from 4 to 15 months. ${ }^{16,28,29}$

This series analysed the demographics, time and methods of treatment, pathology of the primary breast cancer and survival of 8 patients with liver metastases from a breast primary. The longest survivor is now 70 months following her second liver resection.

The patient in this study who has survived the longest had her liver involvement detected 12 years after treatment of her primary breast cancer. Conversely, the single patient so far to die from recurrence of her liver disease had only a short interval between the diagnosis of her primary breast cancer and liver metastases. This would suggest that the length of time from the diagnosis of breast cancer and the detectable liver metastases influences survival. Pocard et $a l .,^{18}$ in a recent study of 65 cases, found that the prognostic factors important for longer survival were a disease-free interval of more than 48 months and the initial stage of the cancer while Carlini et $a .^{21}$ found the only factors of prognostic significance were the control of the primary tumour, the absence of extrahepatic disease and the complete resection of the liver deposits. The limited number of patients in this series precludes statistical analyses. Interestingly, the 2 patients with inoperable disease are still alive 24 and 42 months following open and close laparotomy. This demonstrates that the tumour biology plays an important role in determining survival and it is possible that those patients with synchronous liver metastases or those with a short diseasefree interval have a worse prognosis due the more aggressive and robust nature of the cancer cells..$^{30-32}$

The impact of liver resection in the treatment of liver metastases arising from breast cancer is slowly becoming recognised. There is a select group of patients who stand to benefit from surgical excision of their liver disease. ${ }^{21,16,18,22,26,35,34}$ The overall reduction in the mortality and morbidity associated with liver surgery in the last decade has made this possible by increasing the impact of liver surgery as a safe and reliable way of treating a wide range of benign and malignant liver conditions.

There is more than ever a need for multicentre prospective randomised studies to demonstrate definitely whether liver resection alone or in combination with adjuvant therapy improves long-term survival in patients with breast cancer metastases restricted to the liver. Until then, survival data from similar cases collected prospectively possibly on a regional basis remain the next best evidence. The success of such a prospective study will rely on identifying those patients at risk of developing liver metastases preferably at the asymptomatic stage using CA15-3 measurements, liver ultrasound and/or liver computerised tomography. A better understanding of the molecular biology of breast cancer using technology such as tissue microarray (TMA) may, in the future, allow us predict response to therapy. Clinicians may be able to identify those liver tumours that are best treated by either chemotherapy with or without liver resection ${ }^{35-39}$ or radiofrequency ablation ${ }^{40-42}$ or a combination of both.

\section{References}

1. Hoe AL, Royle GT, Taylor I. Breast liver metastases - incidence, diagnosis and outcome. J R Soc Med 1991; 84: 714-6.

2. O'Reilly SM, Richards MA, Rubens RD. Liver metastases from breast cancer: the relationship between clinical, biochemical and pathological features and survival. Eur J Cancer 1990; 26: 574-7.

3. Petrek JA, Minton JP. Treatment of hepatic metastases by percutaneous hepatic arterial infusion. Cancer 1979; 43: 2182-8.

4. Smalley RV, Carpenter J, Bartolucci A, Vogel C, Krauss S. A comparison of cyclophosphamide, adriamycin, 5-fluorouracil (CAF) and cyclophosphamide, methotrexate, 5-fluorouracil, vincristine, prednisone (CMFVP) in patients with metastatic breast cancer: a Southeastern Cancer Study Group project. Cancer 1977; 40: 625-32.

5. Baur M, Schlappack O, Havelec L, Wrba F, Dittrich C. Prognostic significance of liver metastases as first site of generalisation in patients with breast cancer a retrospective analysis. Acta Med Austriaca 2001; 28: 135-40.

6. Wyld L, Gutteridge E, Pinder SE, James JJ, Chan SY, Cheung KL et al. Prognostic factors for patients with hepatic metastases from breast cancer. $\mathrm{Br} J$ Cancer 2003; 89: 284-90.

7. Canellos GP, Pocock SJ, Taylor III SG, Sears ME, Klaasen DJ, Band PR. Combination chemotherapy for metastatic breast carcinoma. Prospective comparison of multiple drug therapy with L-phenylalanine mustard. Cancer 1976; 38: 1882-6.

8. Kemeny N. The systemic chemotherapy of hepatic metastases. Semin Oncol 1983; 10: 148-58.

9. Atalay G, Biganzoli L, Renard F, Paridaens R, Cufer T, Coleman R et al. Clinical outcome of breast cancer patients with liver metastases alone in the anthracycline-taxane era: a retrospective analysis of two prospective, randomised metastatic breast cancer trials. Eur J Cancer 2003; 39: 2439-49.

10. Coleman RE, Howell A, Eggleton SP, Maling SJ, Miles DW. Phase II study of docetaxel in patients with liver metastases from breast cancer. UK study group. Ann Oncol 2000; 11: 541-6.

11. Savage AP, Malt RA. Elective and emergency hepatic resection. Determinants of operative mortality and morbidity. Ann Surg 1991; 214: 689-95.

12. Belli G, D'Agostino A, Ciciliano F, Fantini C, Russolillo N, Belli A. Liver resection for hepatic metastases: 15 years of experience. J Hepatobiliary Pancreat Surg 2002; 9: 607-13.

13. Heriot AG, Karanjia ND. A review of techniques for liver resection. Ann R Coll Surg Eng/ 2002; 84: 371-80.

14. Jaeck D, Bachellier P, Guiguet M, Feldo M, Vaillant JC, Balladur P et al. Survival benefit of repeat liver resection for recurrent colorectal metastases: 143 cases. Wiad Lek 1997; 50 (Suppl 1 Pt 1): 102-4.

15. Jaeck D, Bachellier P, Guiguet M, Boudjema K, Vaillant JC, Balladur P et al. Long-term survival following resection of colorectal hepatic metastases. Association Française de Chirurgie. Br J Surg 1997; 84: 977-80. 
16. Elias D, Lasser PH, Montrucolli D, Bonvallot S, Spielmann M. Hepatectomy for liver metastases from breast cancer. Eur J Surg Oncol 1995; 21: 510-3.

17. Elias D, Maisonnette F, Druet-Cabanac M, Ouellet JF, Guinebretiere JM, Spielmann $\mathrm{M}$ et al. An attempt to clarify indications for hepatectomy for liver metastases from breast cancer. Am J Surg 2003; 185: 158-64.

18. Pocard M, Pouillart P, Asselain B, Falcou MC, Salmon RJ. Hepatic resection for breast cancer metastases: results and prognosis (65 cases). Ann Chir 2001; 126: 413-20.

19. Yoshimoto M, Sugitani I, Iwase T, Watanabe S, Kasumi F. Therapeutic efficacy of hepatectomy in the treatment of hepatic metastases from breast cancer. Nippon Geka Gakkai Zasshi 1995; 96: 174-9.

20. Yoshimoto M, Tada T, Saito M, Takahashi K, Uchida Y, Kasumi F. Surgical treatment of hepatic metastases from breast cancer. Breast Cancer Res Treat 2000; 59: 177-84.

21. Carlini M, Lonardo MT, Carboni F, Petric M, Vitucci C, Santoro R et al. Liver metastases from breast cancer. Results of surgical resection. Hepatogastroenterology 2002; 49: 1597-601.

22. Santoro E, Vitucci C, Carlini M, Carboni F, Santoro E, Sacchi M et al. Liver metastasis of breast carcinoma. Results of surgical resection. Analysis of 15 operated cases. Chir Ital 2000; 52: 131-7.

23. Cutler SJ, Ardyce JA, Taylor III SG. Classification of patients with disseminated cancer of the breast. Cancer 1969; 24: 861-9.

24. Inoue K, Ogawa M, Horikoshi N, Aiba K, Mukaiyama T, Mizunuma N et al. Evaluation of prognostic factors for 233 patients with recurrent advanced breast cancer. Jpn J Clin Oncol 1991; 21: 334-9.

25. Gelber RD, Cole BF, Goldhirsch A, Rose C, Fisher B, Osborne CK et al. Adjuvant chemotherapy plus tamoxifen compared with tamoxifen alone for postmenopausal breast cancer: meta-analysis of quality-adjusted survival. Lancet 1996; 347: 1066-71.

26. Raab R, Nussbaum KT, Behrend M, Weimann A. Liver metastases of breast cancer: results of liver resection. Anticancer Res 1998; 18: 2231-3.

27. Schneebaum S, Walker MJ, Young D, Farrar WB, Minton JP. The regional treatment of liver metastases from breast cancer. J Surg Oncol 1994; 55: 26-31.

28. Smalley RV, Carpenter J, Bartolucci A, Vogel C, Krauss S. A comparison of cyclophosphamide, adriamycin, 5-fluorouracil (CAF) and cyclophosphamide, methotrexate, 5-fluorouracil, vincristine, prednisone (CMFVP) in patients with metastatic breast cancer: a Southeastern Cancer Study Group project. Cancer 1977; 40: 625-32.
29. Stehlin Jr JS, de Ipolyi PD, Greeff PJ, McGaff Jr CJ, Davis BR, McNary L. Treatment of cancer of the liver. Twenty years' experience with infusion and resection in 414 patients. Ann Surg 1988; 208: 23-35.

30. Chelouche LD, Price JE. Therapeutic intervention with breast cancer metastasis. Crit Rev Eukaryot Gene Expr 2002; 12: 137-50.

31. Price JE. Host-tumor interactions in the progression of breast cancer metastasis. In Vivo 1994; 8: 145-54.

32. Sledge Jr GW. Implications of the new biology for therapy in breast cancer. Semin Oncol 1996; 23: 76-81.

33. Elias D, Cavalcanti DA, Eggenspieler P, Plaud B, Ducreux M, Spielmann M et al. Resection of liver metastases from a noncolorectal primary: indications and results based on 147 monocentric patients. J Am Coll Surg 1998; 187: 487-93.

34. Maksan SM, Lehnert T, Bastert G, Herfarth C. Curative liver resection for metastatic breast cancer. Eur J Surg Oncol 2000; 26: 209-12.

35. Assersohn L, Gangi L, Zhao Y, Dowsett M, Simon R, Powles TJ et al. The feasibility of using fine needle aspiration from primary breast cancers for CDNA microarray analyses. Clin Cancer Res 2002; 8: 794-801.

36. Cleator S, Parton M, Dowsett M. The biology of neoadjuvant chemotherapy for breast cancer. Endocr Relat Cancer 2002; 9: 183-95.

37. Gruvberger SK, Ringner M, Eden P, Borg A, Ferno M, Peterson C et al. Expression profiling to predict outcome in breast cancer: the influence of sample selection. Breast Cancer Res 2002; 5: 23-6.

38. Sgroi DC, Teng S, Robinson G, LeVangie R, Hudson Jr JR, Elkahloun AG. In vivo gene expression profile analysis of human breast cancer progression. Cancer Res 1999; 59: 5656-61.

39. Zhang D, Salto-Tellez M, Putti TC, Do E, Koay ES. Reliability of tissue microarrays in detecting protein expression and gene amplification in breast cancer. Mod Pathol 2003; 16: 79-85.

40. Carditello A, Scisca C, David A, Stilo F, Basile M. Radiofrequency ablation in primary and secondary liver tumors. Chir Ital 2002; 54: 83-6.

41. Vogl T, Mack M, Straub R, Zangos S, Woitaschek D, Eichler K et al. Thermal ablation of liver metastases. Current status and prospects. Radiologie 2001; 41: 49-55.

42. Livraghi T, Goldberg SN, Solbiati L, Meloni F, lerace T, Gazelle GS. Percutaneous radio-frequency ablation of liver metastases from breast cancer: initial experience in 24 patients. Radiology 2001; 220: 145-9. 